\title{
A CRITICAL DISCOURSE APPROACH TO BENJAMIN MARTIN'S PREFACE TO AN INTRODUCTION TO THE ENGLISH LANGUAGE AND LEARNING (1754) ${ }^{1}$
}

\author{
Dolores Fernández MarTínez \\ Universidad de Las Palmas de Gran Canaria \\ dolores.fernandez@ulpgc.es
}

\begin{abstract}
The purpose of the present paper is to contribute to the depiction of Martin's role as a grammarian by analysing the preface to his grammar An Introduction to the English Language and Learning (1754). By using a Critical Discourse Analysis approach and a method based on systemic functional grammar, this study intends to describe the discourse structures used in the preface to fulfil its advertising function and persuade the addressee as a potential buyer or user of the grammar. Martin's preface is characterised by a peculiarly exaggerated and aggressive tone and by a strong emphasis on the religious implications of education, all of which confer some distinction to Martin within the discourse community of eighteenth-century grammarians.
\end{abstract}

Keywords: English grammars, eighteenth century, Critical Discourse Analysis, systemic functional grammar, transitivity structures, Benjamin Martin.

\footnotetext{
1 This paper is part of the Research Project ULPGC2014-02, funded by the Vicerrectorate for Research, Development and Innovation (Universidad de Las Palmas de Gran Canaria).
} 


\title{
UNA APROXIMACIÓN CRÍTICA DISCURSIVA AL PREFACIO DE BENJAMIN MARTIN A AN INTRODUCTION TO THE ENGLISH LANGUAGE AND LEARNING (1754)
}

\begin{abstract}
RESUMEN. El presente trabajo pretende contribuir a perfilar el papel de Martin como gramático a través del análisis del prefacio a su gramática An Introduction to the English Language and Learning (1754). Utilizando una aproximación al Análisis Crítico del Discurso y un método basado en la gramática sistémicofuncional, el objetivo de este estudio se centrará en describir las estructuras discursivas utilizadas en el prefacio para dar forma a su función propagandística y persuadir al lector como comprador potencial o usuario de la gramática. El prefacio de Martin se caracteriza por un tono peculiarmente exagerado y agresivo, y también por un fuerte énfasis en las implicaciones religiosas de la educación. Todas estas características aportan un rasgo de distinción a Martin dentro de la comunidad discursiva de gramáticos del siglo dieciocho.

Palabras clave: Gramáticas inglesas, siglo dieciocho, Análisis Crítico del Discurso, gramática sistémico-funcional, estructuras de transitividad, Benjamin Martin.
\end{abstract}

Received 20 March 2017

Revised version accepted 29 September 2017

\section{INTRODUCTION: MARTIN IN HIS CONTEXT}

In John R. Millburn's (1976) biography, Benjamin Martin: Author, InstrumentMaker, and 'Country Showman', Benjamin Martin is depicted as a remarkably versatile character, especially active as a lecturer and maker of scientific instruments of various kinds. However, as stated by Tieken-Boon van Ostade (1982) in her study 'Benjamin Martin The Linguist', there is one aspect of Millburn's biography that should have been treated more extensively, namely, his role as a linguist. Despite Tieken-Boon van Ostade's remark, Martin's linguistic profile remains rather unexplored. In recent research carried out by the author of this paper (FernándezMartínez 2016) on a corpus of prefaces to eighteenth-century English grammars, Benjamin Martin's preface to An Introduction to the English Language and Learning (1754) became the object of interest to the author because of its distinctive linguistic qualities. The characteristics of Martin's preface make it different from the grammars included in the selected corpus, mainly because of its rather aggressive and emphatic nature, and the attention paid to the critical religious dimension that education acquires. The aim of this paper is to deepen understanding of the discourse structures used in Martin's preface to fulfil its advertising function and persuade the addressee as a potential buyer or user of the grammar. 
A CRITICAL DISCOURSE APPROACH TO BENJAMIN MARTIN'S PREFACE TO AN INTRODUCTION TO...

The eighteenth century, and in particular the second half of the century, witnessed an unprecedented increase in the production of English grammars. The proliferation of grammars can partly be related to the intensification of social mobility, especially during the second half of the century, and the need for the codification of the English language (Tieken-Boon van Ostade 2008a: 10). As the Industrial Revolution was progressing, rising middle classes began to aspire to higher positions in society. An ambitious middle class tried to have access to correct usage of the language and prestigious language variants. Meanwhile, grammarians became aware of the linguistic implications of the demands of social mobility: "grammarians of this period are seen as wanting to 'fix' the English language in order to achieve the stability in language that they hoped to retain in government and in society" (Beal 2004: 95).

Both grammar writers and publishers were in competition with each other for a share of the readership's market of English grammars. The market created by the wide readership included the children of ambitious middle-class parents. Some grammarians also advocated the teaching of English to girls of all classes since they were denied entry to grammar schools and universities (Beal 2004: 103). The battle for the control of the editorial market led publishers to employ strategies that would make their books more attractive to potential buyers (Tieken-Boon van Ostade 2008c: 121). In such a competitive context, prefaces to the grammars were used to convince potential buyers of the positive qualities of the grammars. Prefaces, therefore, fulfilled an "advertising function" (Watts 1995: 154). Genette (1991) has referred to the pragmatic function of prefaces as paratextual elements in terms of their authorial or editorial intention but also in their purpose to assure the presence of the work they accompany and its reception. "Certain elements of the paratext are effectively addressed to [...] the public in general [...]. Others are addressed more specifically, and more restrictively, to the readers of the text alone: this is typically the case of the preface" (Genette 1991: 267). In any case, the term paratext embraces different types of textual elements that must be examined individually, "genre by genre" (Genette 1991: 269).

As Watts (2008: 55) states, to delineate the discursive strategies that are common to the discourse community of English grammar writers, grammars themselves have to be investigated more closely. Grammarians displayed some common discourse strategies and socio-cognitive assumptions that justified their being considered a discourse community (Watts 1995, 2008). ${ }^{2}$ Their grammars

\footnotetext{
2 Grammar writers were thus in competition with one another, but there was also a certain amount of communication in writing among some of them. As Watts (2008) explains, rather than constituting a community of practice, grammar writers formed a discourse community. Even though they did not share it, grammarians had a common enterprise that led to regular textual borrowings amongst them. However, because there was no truly mutual engagement between them, they could not be considered a community of practice.
} 
represented a form of discourse with conceptual and structural similarities, and it was in the prefaces to their grammars that their shared discourse structures and ideologies were particularly noticeable. However, although prefaces to eighteenth-century English grammars have not been of much concern until now, Watts (2008) opened a pathway to more research in this area. ${ }^{3}$

In Fernández-Martínez (2016), twenty-one prefaces to eighteenth-century English grammars were analysed to establish some of the discourse structures that characterised the discourse community of English grammarians. ${ }^{4}$ This study formulates a proposal of genre structure, applicable to the corpus selected, in terms of which the prefaces are composed of three stages: Construction, in which the process of creation of the grammar is explained; Amelioration, where the text focuses on potential readership as beneficiaries or buyers of the grammar; and Contact, where a line of communication between author and readership is created, allowing the transfer of focus in the text from the writer to the reader. The stages suggested in this paper represent a personal application to the prefaces under study of both Martin's (1992) concept of genre and of the genre structures exemplified by Martin and Rose (2003: 7-15). Martin defines genre as a semiotic system that serves the social purpose of language use: "a staged, goal-oriented social process" (Martin 1992: 505; Martin and Rose 2003: 7). Genre systems are formulated on the grounds of similarities and differences between text structures, so text structure is generated at the level of genre, thereby producing the different text types.

Martin's preface contains eighteen pages (starting from page $v$ until page xxii). Through these three stages of genre, it contrasts a past and present context of deficient grammar learning with an improved learning system that should rely on the use of the grammar presented. This content does not differ from what English grammars in the eighteenth century reflected: "Like the authors of selfhelp books today, grammarians of the eighteenth and nineteenth centuries had to establish that there was a problem in order to sell their solutions to

\footnotetext{
3 Studies such as the ones undertaken by Rodríguez-Álvarez and Rodríguez-Gil (2013) and DomínguezRodríguez and Rodríguez-Álvarez (2015) have contributed to the characterisation of the prefatory texts of eighteenth-century grammars. Increasing attention to the study of the eighteenth-century can also be attested to by the availability of online resources, such as the Eighteenth-Century English Grammar (ECEG) database. This electronic database of eighteenth-century English grammars compiled by Rodríguez-Gil and Yáñez-Bouza (2010) aims to meet the demands of scholars working on the field of English grammars by offering bibliographic information about English grammars, along with biographic information of the grammar-writers.

4 The corpus under analysis was retrieved from ECEG following these parameters: (i) England for place of birth of the author, (ii) English grammar for type of work, and (iii) institutional and mixed for target audience (instruction).
} 
A CRITICAL DISCOURSE APPROACH TO BENJAMIN MARTIN'S PREFACE TO AN INTRODUCTION TO...

readers anxious to avoid being censured for grammatical solecism" (Beal 2004: 92-93). However, as will be shown in the present paper, Martin's preface employs discourse structures that offer a particular view of those conditions.

The study above (Fernández-Martínez 2016) applied, essentially, a Critical Discourse Analysis oriented question that explored Watts' idea of prefaces as a site for communicating of a discourse community. Thus, it could also be suggested that Martin's preface may have placed him as a distinctive author within the discourse community of eighteenth-century English grammarians, at least with regards to the grammarians selected in this study. In the biography published by Millburn (1976), Martin is depicted as a remarkably versatile character who was especially active as a lecturer and maker of scientific instruments of various kinds, one of the best-known men of science of his day. His diverse interests and the feeling that he could improve whatever came under careful examination led him to undertake a range of projects with much success. Martin's abilities and skills are also described in The Oxford Dictionary of National Biography (2004). As it is explained there, Martin taught a wide variety of disciplines, from writing to astronomy, in the school at Sussex he established in his late twenties. There he began to write, his first publication being The Philosophical Grammar (1735). Martin devised his own microscope because one of the major fields of expertise for him was optics. By 1742, Martin tried to earn a living giving lectures on experimental philosophy, first in Reading and later in Bristol and Bath. A greatly expanded version of his lectures was published in the two volumes of Philosophia Britannica (1747). From 1746 until 1756, he was travelling and lecturing mainly on experimental philosophy, although he also produced Institutions of Language (1748), Lingua Britannica Reformata, A New English Dictionary (1749), and his most ambitious literary work, The General Magazine of Arts and Sciences, Philosophical, Philological, Mathematical, and Mechanical (1755). When he abandoned travelling, he began to trade as an instrument maker and, more specifically, as an optician, and also gave evening lecture courses in London. He died in 1782 after being declared bankrupt, probably the result of a suicide attempt.

Tieken-Boon van Ostade (1982: 129) diminishes the importance of Martin's abilities: "Martin's versatility is thus not really outstanding in a period in which there were as yet no true specialists, at least as far as linguistics is concerned." On the contrary, although Tieken-Boon van Ostade (1982: 121) admits that the biography was not aimed at a public of scholars interested in his linguistic side, she believes that there is one aspect in Millburn's biography that should have been treated more extensively, namely, his role as a linguist. ${ }^{5}$ Martin's dictionary has attracted

\footnotetext{
5 In the eighteenth century, the typical occupation of grammarians was primarily that of schoolteacher, although grammars were also written by clergymen, booksellers, and other apparently self-proclaimed
} 
the attention of scholars (e.g., Wells 1973; Starnes and Noyes 1991), and some research has been carried out on his scientific instruments (e.g., Millburn 1973). Nevertheless, Martin has not been of much concern among scholars in more recent research on eighteenth-century grammatical traditions. Evidence of this is provided in Tieken-Boon van Ostade's (2008b) edited book Grammars, Grammarians and Grammar Writing in Eighteenth-Century England, where only a reference to Martin's grammar can be read when Auer (2008: 61) mentions "lesser-known grammars that were never reprinted such as Kirkby (1746) and Martin (1754)". In 'Benjamin Martin the Linguist', Tieken-Boon van Ostade (1982) highlighted his role as a linguist through two grammatical works, Institutions of Language (1748) and An Introduction to the English Language and Learning (1754), and one dictionary, Lingua Britannica Reformata (1749). Indeed, despite Tieken-Boon van Ostade's remark, Martin's linguistic profile remains rather unexplored.

The purpose of the present study is to contribute to depicting Martin's role as a grammarian by analysing the preface to his grammar An Introduction to the English Language and Learning (1754). ${ }^{6}$ This researcher intends to argue that far from being overlooked, Martin's linguistic profile deserves wider recognition. Concerning his preface, its particularly aggressive and powerful tone, along with the emphasis laid on the religious implications of education, may have helped enhance the persuasive purpose of the preface and confer some distinction to Martin within the discourse community of eighteenth-century grammarians. In addition, the focus on the religious dimension of education is not to be underestimated either. Although Reyk (2009: 426) considers the role of religion to have received little attention, he states: "There was disagreement over the actual state of religious provision at the public schools and universities, but all were agreed that the most important aim of education at both types of institution was the formation of Christian men"?

\section{THEORETICAL AND METHODOLOGICAL FRAMEWORK}

Critical Discourse Analysis is an interdisciplinary approach that considers discourse an instrument of power and ideological control (e.g., Fairclough 1989,

\footnotetext{
grammarians. It must be noted that, according to current standards, grammarians in the eighteenth century were not language experts "simply because experts, as they have come to be considered nowadays, did not exist for practically any field" (Chapman 2008: 21).

${ }^{6}$ An Introduction to the English Language and Learning was Martin's second grammatical work. It was first published in 1754 and went through three editions. The second and the third editions came out in 1756 and 1766, respectively.

7 Reyk (2009) offers a detailed examination of the written debate on religious education in the eighteenth century in which discipline and religious education were inextricably tied and considered together.
} 
A CRITICAL DISCOURSE APPROACH TO BENJAMIN MARTIN'S PREFACE TO AN INTRODUCTION TO...

1995). Critical Discourse Analysis promotes the application of critical thought to any text, situation, or social problem to uncover the implicit strategies that exert a persuasive effect on the reader or hearer. Considering those aspects, it could be argued that the aim of this study fits in with a Critical Discourse Analysis perspective. More specifically, the process of naturalisation proposed by Fairclough (1989) may help explain the purpose that sustains some of the discourse structures in Martin's preface, and overall, the strong persuasive effect behind the preface. Through the process of naturalisation, discourse types lose their ideological character because ideologies are presented as common-sense assumptions: "Naturalization is the royal road to common sense" (Fairclough 1989: 92). Dominant discourses are subject to a process of naturalisation by means of which they lose their connection with particular ideologies and turn into the common-sense practice of the institution they represent. A discourse type will cease to be seen as one among several possible ways of viewing things and will become natural and legitimate, presenting simply the way things are. In order to acknowledge naturalisation, a distinction should be made "between the superficial common-sense appearances of discourse and its underlying essence" (Fairclough 1989: 92). Hence, this analysis will try to unveil how some discourse structures naturalise the text to present as natural and normal a reality as possible in which the reader is to be convinced of the benefits of Martin's grammar for the education of children.

Critical Discourse Analysis derives from several theoretical backgrounds, and there is not a specific methodology considered as characteristic. Various types of texts have been analysed using a Critical Discourse Analysis framework, such as political speeches (e.g., Wang 2010), educational texts (e.g., Rogers 2011) or newspapers (e.g., Teo 2000), to name but a few. Despite the fact that prefaces have been a subject of interest for discourse analysis since the Old English period (e.g., Discenza 2001; Harbus 2007), prefaces to eighteenth-century English grammars continue to be unexplored from a Critical Discourse Analysis point of view. Accordingly, this paper addresses some deficiencies by gathering Critical Discourse Analysis, prefaces to eighteenth-century English grammars, and Martin's preface in particular.

Although Critical Discourse Analysis has been quite eclectic from a methodological point of view, Critical Discourse Analysis and Systemic Functional Linguistics have remained in an ongoing exchange since they both primarily share a dialectical view of language and society. Systemic Functional Linguistics, which studies the functions that language serves in society, has turned into the most extensively used method throughout their historical relationship (e.g., Martin 2000; Young and Harrison 2004). More specifically, since its first edition in 1985, Halliday's (2004) Introduction to Functional Grammar has traditionally been regarded as one of the most suitable instruments for the analysis of the text (e.g., Fairclough 1989, 1995). 
The analysis carried out in the present paper will focus on learners as the main participants in the text, either as beneficiaries or as victims of education, as well as on the role of parents and their responsibility regarding the education of children. These participants may be considered the addressees of Martin's grammar and more generally, the prospective users and buyers of the grammar. To this end, the researcher follows Martin's (1992: 129) terminology, where the term participant is proposed to refer to how individuals who are capable of functioning as agents in transitivity structures (see Halliday 2004: 168-305) perform in the text. Halliday's transitivity structure represents reality regarding the three components: participants, processes, and circumstances. The set of processes proposed by Halliday (2004: 168-259) range from material actions (representing processes of the external world) to mental ones (construing inner experience), relational processes (identifying and classifying), behavioural (outer manifestations of inner workings), verbal, and existential. As far as meaning is concerned, circumstances refer to the location of an event in time or space, its manner, or its cause (Halliday 2004: 260-261). By using these tools, we will try to illustrate how education, through either proper or unsuccessful teaching methods, affects learners, and how learners and prospective users of the grammar are described in the preface, namely the actions they perform, the relationships established between them, and the attitudes they show towards education. In the analysis of transitivity constructions, lexical cohesion devices will also be taken into consideration to study the effect of vocabulary within transitivity structures and at a discourse level. "Just as ellipsis and substitution take advantage of the patterns inherent in grammatical structure, [...] lexical cohesion takes advantage of the patterns inherent in the organization of lexis" (Halliday 2004: 570). Martin's preface is characterised by the extensive use of processes of repetition - considered by Halliday (2004: 571) "The most direct form of lexical cohesion" -, synonymy, and ultimately, a complex network of aggressive, and at times, pejorative terms that seem to collocate in the preface and, overall, add great emphasis and intensity to the text to provoke the reaction of the reader. However, the most personal characteristic of Martin's preface is the collocation, namely, "a tendency to co-occur" (Halliday 2004: 577), or rather the naturalisation of collocation, of educational and religious terms to alert the reader to the adverse effects of poor quality education and its severe effect on a religious sphere.

\section{DISCUSSION}

The prefaces to eighteenth-century English grammars under study in FernándezMartínez (2016) contain discourse structures in which the quality of existing grammars and the work undertaken hitherto by grammarians are criticised. At the 
A CRITICAL DISCOURSE APPROACH TO BENJAMIN MARTIN'S PREFACE TO AN INTRODUCTION TO...

same time, the different discourse structures underlie the adverse consequences for the learner. Martin's preface is particularly powerful and emphatic in this sense, which confers some singularity to the way in which the text fulfils its persuasive function over the reader. Martin's preface is characterized by complex transitivity patterns that, as will be explained throughout this section, combine various processes and participants in a systematic and purposeful way. These transitivity configurations become more intense by including an amalgam of aggressive and somewhat pejorative terms, along with some emphatic lexical and grammatical devices (e.g., emphatic adjectives, repetition, synonymy, and comparative and superlative forms). Furthermore, a remarkable religious dimension of education pervades the text, contributing to naturalising the impression of a disastrous learning situation with far-reaching catastrophic consequences.

As already mentioned, this analysis will focus on the role of the users, learners, or potential buyers of the grammar as described through transitivity structures. More specifically, this paper aims to study how transitivity patterns depict these participants to exert an influential function on the addressees and persuade them to buy or use the grammar presented. Potential users as learners appear mainly through the third person, either singular or plural, although they are also integrated into the references of the first-person plural (we). The third person materialises in the preface through a variety of participants that go from references to children, youth, learners, scholars, or parents, to their religious identification as Christians. Methods and participants presented both through the first-person plural (we/our) and third person (children, youth, learners, scholars, parents, and Christians) will be analysed in this section, which will be structured taking into account these two main categories: third person and first-person plural. In either case, participants are presented either as victims of previous poorly implemented methods or as potential beneficiaries of the new grammar. In either case, the transitivity structures used in the text to portray them exert a persuasive role over the reader both to alert him to the impractical nature of previous methods and show the merits of Martin's grammar.

\subsection{THIRD PERSON}

Transitivity structures that describe traditional grammars or teaching methods are also included in this analysis since they influence the perception of the quality of the grammar presented regarding the benefits it may offer to the learner. Martin naturalises a categorical discourse wherein some negative items (insufficient, 
unnatural, absurd) refer to the characteristics of the teaching methods and the results of their application: "But what is most extraordinary in our vulgar Methods [...] it will appear to be every Way insufficient, unnatural, and absurd, and certainly the most prophane, if not impious way [...]" (viii-ix). By means of both attribute verbs (is, appear) and the string of likewise pejorative adjectives (insufficient, unnatural, absurd), previous grammars and methods are discredited. Relational attribute structures (it be the most essential Part, the usual Method they all pursue of [...] is a very bad one) are included again to assess the facts delineated, whereas the author places himself as a centre of reflection through a cognitive process (consider) in order to support the reliability of the message: "And this brings me to consider the Subject of Reading and Discourse [...] nothing has been more neglected in English Education, though it be the most essential Part" (vi), "though I have found, by many Year of Experience, that the usual Method they all pursue of [...] is a very bad one [...]" (vii-viii). The learner is placed within a particularly unfavourable environment of learning flaws and neglect, which stresses the necessity of grammatical assistance, also emphasised by the repetition of the adjective necessary: "But Grammar is the only one Thing necessary [...]" (vi), "as is the usual Method, which I know to be a very bad one by many Years Experience. To this I have premised, what is necessary to the [...]" (xv). Throughout the preface, transitivity patterns include attributive structures (mainly with the verb be) that interfere in the impartiality of the message.

A recurrent complex transitivity pattern used throughout the preface combines relational attributive structures, whereby the reality described is assessed (would it not appear an amazing Thing), with mental processes of perception (to see) whose participants (or sensers, in Halliday's terminology) act as witnesses of the facts presented. Throughout the preface, Martin does not purely deliver information. Rather than describing events, he evaluates them and places the reader as an observer to confer veracity to the text. In this case, learners are portrayed as negatively affected by existing learning methods, namely, as children without judgement (senseless Boy and Girl): "would it not appear an amazing Thing to any one but a Christian, to see these Writings made the vulgar Praxis [...] to every senseless Boy and Girl [...]" (ix). Martin refers to profound consequences that go beyond an educational context and affect religion. Religious terms depict the learner as being more than a learner, a Christian, and as can be observed in the following structure, the way of teaching through these methods as prophane and impious, with further emphasis laid through synonymy (prophane, impious) and superlative forms (the most prophane). Accordingly, collocation of religious and

\footnotetext{
8 Segments from Martin's preface (1754) are referred to by page number. Words in italics stay as they are in this version.
} 
A CRITICAL DISCOURSE APPROACH TO BENJAMIN MARTIN'S PREFACE TO AN INTRODUCTION TO...

educational lexical items seems to be regarded as common sense. Martin's preface is especially critical and explicit in his statements. Martin's view of education is marked by its precariousness. He denounces the negligence of past and current teaching approaches by also presenting their results with children, who are depicted as incompetent learners: senseless Boy and Girl, but also with barren, uncultivated Mind: "but the barren, and uncultivated Mind shews the Man in a deplorable, and shocking Contrast, susceptible of any Thing that is bad" (xx). Learners affected by previous defective grammars perform as double participants in this transitivity structure, namely, in Halliday's terms, both as an actor and as a goal. Therefore, apart from being damaged by previous and existing teaching approaches, learners become victims of themselves and of their intellectual deficiencies. What is more, in a deprecating tone, learners are portrayed as defective humans prone to temptation (susceptible of any Thing that is bad).

The third person (the Child) is also placed in a situation of difficulties and obstacles to surmount. Material verbs performed by children (accent) are inserted in wider transitivity structures that specify how the accomplishment of these tasks is hindered by erroneous educative systems of instruction. The actions of learners are influenced or determined by the circumstances imposed by teaching methods, which act as activators (obliges, makes) of the actions carried out by the learner: "it obliges the Child to accent some Words [...] it makes it very difficult for him to accent [...]" (viii). Opposing the previous transitivity structures, the new approach suggested through Martin's grammar portrays the scholar to his full potential in the execution of the tasks (is perfect $\mathrm{in}$ ) in the following relational attributive structure: "After the Scholar is perfect in Spelling, the next Thing necessary [...]" (xvii). As shown in the following examples, a system of carefully arranged adjectives and adverbs (genuine, well, judiciously, proper, sufficient) qualify what should be considered an authentic and convenient education, whereas adverbs materialise in circumstantial elements that support the felicity of the actions undertaken. On the other hand, verbs such as enable or exercise function as facilitators of the educative duties assumed, activating positive results: "Plan of general and genuine Education [...] as will enable a Person to speak; read, and write, well and judiciously [...]" (xiii), "And the Third Part must consist of a proper and sufficient Praxis, for exercising the Scholar in the Art of reading well [...]" (xiv). Compared to it, the transitivity structure common Experience but too much evinces accentuates the truthfulness of the message in which the imperfection of the mental action of cognition (understand) carried out by learners is enhanced by the contrast between too much (as a circumstantial element) and too little. Expressing quantity or degree, both components contribute to increasing the gap between the advantages and detrimental effects of previous grammars and the new grammar, 
respectively: "common Experience but too much evinces how little our Youth understand of either, after the first seven Years of the customary Education" (v).

In the following transitivity arrangement, the third person becomes more specific through the general reference Youth. The accomplishment of material creative processes (form, construct) relies on the actions of the instructors (must be instructed), supporting the idea of the youth's lack of self-sufficiency in educational matters: "The Second Part is that, by which the Youth must be instructed how to form, or construct a sentence [...] in such a natural and proper Manner [...]" (xiv). However, what this structure unveils is a sort of anticipation of the success of this new grammar. Transitivity patterns fix the actions of the third person to follow, indicating the improvement achieved by learners. Circumstantial elements, rather than merely providing information about manner, exert a strategic purpose since they qualify methods by transferring to them the same features (natural and proper). The role of youth in the previous transitivity arrangement opposes his function in the following one, where attributive structures (what is most extraordinary, it will appear to be [...J) are employed to evaluate the results of traditional methods in an emphatic manner. The way of instructing youth shows a disrespectful attitude towards God, which is enhanced through synonymy (prophane, impious) and superlative forms (the most prophane) in the attributive element: "But what is most extraordinary in our vulgar Methods [...] it will appear to be every Way insufficient, unnatural, and absurd, and certainly the most prophane, if not impious Way that possibly could be thought of, for instructing Youth in the Art of Reading" (viii-ix). This discourse configuration allows for attributive constructions that show emphatic amazement (what is most extraordinary), but above all, that intentionally transfer the same judgement onto the reader. In addition, the author uses the passive with mental, cognitive process (that possibly could be thought of) to highlight the attributive meaning. Therefore, rather than merely describing, the author evaluates the actions of the learners by integrating them into higher transitivity structures of assessment.

By means of the third person, the learner is depicted as being severely affected by the grammatical deficiencies and limitations of the teaching methods of the past and present to make the learner aware of the necessity of grammatical assistance. The author fixes a model of action to be followed by the student, although far from merely presenting it, Martin imposes it strategically. Thus, transitivity structures do not merely reflect how learners behave or act but how they should or have to. The examination of lexical items evinces this discernible contrast. A detailed system of adjectives creates a double layer of learning conditions that despite concentrating on the preceding and present stage of unproductive learning, also refer to the subsequent phase of educational improvement. Through the transitivity patterns 
A CRITICAL DISCOURSE APPROACH TO BENJAMIN MARTIN'S PREFACE TO AN INTRODUCTION TO...

associated with the third person, the preface evinces the disparity between the implementation of both proper and mistaken teaching methods. The capacity of teaching methods either to enable or to hinder the actions of learners is illustrated through some complex transitivity structures. Some processes (e.g., enable, makes) act as hinge actions that allow the learner to perform either correctly or mistakenly, whereas through circumstantial elements, the potential of the learner is presented at its fullest or lowest potential. In either case, the learner is described as lacking autonomy, as an entity in the hands of the methods applied and unable to control his own educative destiny.

A position of conformity with vulgar methods also evinces the corruption of adults and makes them responsible for producing inept children. Martin's preface creates a network of responsibility where traditional methods and the implicit consent of parents' function as joint determinants that distract children not only from religion but also from their own happiness: "Parents must be adjudged guilty of Inhumanity to their Children, when they neglect to give them a Scientific Education. Nothing can be more astonishing, than to see how anxious they are in amassing Wealth for them, and at the same Time, with what Indifference and Insensibility they suffer the wretched Poverty of their Minds" (xx-xxi). Different layers of processes are employed to portray parents as neglecting the education of their children. The use of the passive (must be adjudged), in combination with the attributive structure Nothing can be more astonishing, and the inclusion of a superlative form (more astonishing), turn into an implicit invitation to the reader to judge the behaviour of parents. This incitement is further supported by the understood testimony of the first-person plural with a verb of perception ( $t o$ see). Through different levels of processes that mix attributive patterns (anxious they are), material processes with abstract meaning (amassing), and behavioural verbs (suffer), the preface depicts the attitude of abandonment and carelessness of parents as regards the education of their children. Indeed, Martin is highly critical of the role of parents, as he focuses on them as misleading elements in the education of their children, reproaching them for their Inbumanity and greediness (anxious [...] in amassing Wealth), whereas processes and circumstances in transitivity structures show neglect and Indifference and Insensibility, respectively. Nevertheless, Martin seems to be excessive and exaggerated in his attempt to bestow upon parents the responsibility of educational collapse. To the categorical adjectives used to measure the education precariousness previously mentioned, another emphatic adjective (astonishing) in the attributive structure Nothing can be more astonishing must be added, as well as more references to its impact on learners (wretched Poverty of their Minds). Deficient education methods trigger destructive and hostile behaviour in children. 
Traditional education becomes a harmful instrument that causes considerable damage to children, both physically and morally: "How are those Writings, which were intended to give the greatest Pleasure and Solace to the Mind, often made the Cause of bodily Pain and Wretchedness to Children" (x-xi). Therefore, the preface moves between extremes and tackles different levels of implication. More specifically, this sentence opposes intention (intended to) and reality or outcome (made) by contrasting the highest expectations with the destructive results that pervade body, mind, and feelings, moving thus from the greatest Pleasure and Solace to the Mind to bodily Pain and Wretchedness. Distinctiveness in Martin's preface emerges from a combination of transitivity patterns and lexical cohesive devices that provide a framework of discourse intensity and emphasis to the text. Above all, the text comes from a view of education laden with strong religious connotations where education seems to be transformed into a kind of religion itself. Throughout the preface, innumerable religious associations are conferred to education to illustrate how those vulgar methods degenerate into an irreverent behaviour towards religion. A bad learning method implies a lack of respect for religious beliefs, a kind of insult to religion whereby an incompetent learner becomes a bad believer as well: "How are those Scriptures of Truth, those Written Laws of God [...] torn to Pieces, and trampled under our Feet while Children!" (x). Transitivity structures exemplify the destructive behaviour towards religion that emerges from an immoral education by means of aggressive material processes (torn to Pieces, trampled under our Feet). The preface thus naturalises a straight connection between education and religion regarding the way a deficient education will have a direct and adverse effect on religion.

\subsection{FIRST-PERSON PLURAL}

The reader is predisposed to evaluate the situation described as being normal (it is not seldom), whereas the first-person plural (we) integrates reader and writer as witnesses of the reality being denounced: "it is not seldom that we see a Genius buried in Obscurity [...]" (xviii-xix). By means of the first-person plural, or inclusive we (see, e.g., Fairclough 1989), the author creates an emotional state of empathy and closeness with the reader, sharing the reader's feelings of frustration, which facilitates the subtle imposition of subjectivity in the message, in this case, to illustrate that the persistence of traditional methods may lead to horrible consequences for the brightest. Now, the third person is portrayed in rather macabre circumstances (a Genius buried in Obscurity), by contrasting the highest potential of learners (Genius) with the most frustrating and darkest destiny that nullifies any prospects of success (buried in Obscurity). In the structure "Is it not very preposterous to learn to read without Understanding [...]" (xi), the 
A CRITICAL DISCOURSE APPROACH TO BENJAMIN MARTIN'S PREFACE TO AN INTRODUCTION TO...

writer also takes for granted the role of the reader as a spectator of the events. The learner appears as an elided agent (to learn) in the attributive construction Is it not very preposterous [...], whereby the writer extends an implicit invitation to the reader to share his view about the failure of existing teaching approaches. In this case, the combination of mental processes (learn, read) is nullified by the circumstantial element of manner (without Understanding).

The analysis of the first-person plural (we) in transitivity structures proves the limitations of teaching methods through the inability of these participants to perform as learned people: "because, without such Knowledge, we cannot converse with Men of Learning, we cannot understand Books of Science, nor can we read or write properly [...]" (vii). The repetition of inability (cannot) and the range of processes involved (to be precise, verbal, cognitive, and material-creative), together with the emphatic unproductive circumstances (properly), combine to alert the reader against the poor quality of education, and above all, against the damaging effect, at different levels, it has on children.

In some structures the first-person plural (our) is used to exert a strategic effect of closeness on the reader whereby the writer presents to the reader what seems to be a shared undeniable reality: "And indeed, I know of no other Instance, that shews so plainly, how callous our Minds may be rendered by Custom, and altogether insensible of Impressions from the most interesting and sacred Principles in Nature, viz. those of Religion, and the Happiness of our Children (ix)". In this sentence, the author (I) displays his authority by providing a rational background through the mental verb of cognition know (I know). The transitivity structure made of the verb shews plus the circumstantial element so plainly underlies the self-evident nature of the information provided, where the first-person plural appears as an insensible mind as the result of traditional teaching methods. Once again, synonymy (callous, insensible) and superlative forms (the most interesting and sacred) are employed to reproach us for passivity. Martin is direct and energetic when it comes to criticising society for a somewhat conformist attitude towards education, which also affects the essence of a human being, namely, religion and happiness. Martin exploits the side of responsibility as a discourse strategy to provoke a feeling of guilt and an active response on the part of the reader. Thus, the preface establishes a close correlation between education, religion, and happiness in which we should assume total responsibility. Believers who have been indoctrinated by education demonstrate contempt for religion. Nevertheless, being tolerant of traditional teaching methods turns us into accomplices. The author seems to question the moral integrity of adults because of their indifference regarding the happiness of their children. In this sense, the preface aims to cause a spontaneous reaction in adults. More importantly, 
the explicit references of the process whipp'd to physical mistreatment serve to introduce the idea of punishment like penance in their incapacity to learn properly: "How are we reproached and whipp'd in our Non-age, for not being able to read [...]" (xi). Vulgar methods corrupt good human condition and produce traitors to religion so that a connection could be found between educational inabilities and punishment. Martin depicts a rather demoralizing picture of both children, as victims of their parents' neglect, and of adults, who give their consent.

Throughout the preface, the first-person plural performs as a witness of events. Facts are not merely presented but supported by the perception of both reader and writer as a united entity to confer credibility and authenticity to the text: "we often see Children bred up without any Erudition at all; and though the Parents be in opulent Circumstances; yet they appear Niggards in nothing so much as the little Learning they bestow on their Children; if they purchase it, it must come very cheap; no Man is so ill paid as a School-Master [...]" (xxi).

And is it not extremely probable, that the Book we have so frequently bedrivelled, daubed, and pulled to Pieces at School, should become the Object of our future Indifference, Contempt, or Aversion? And may not the Grounds of Deism, and Infidelity in general, be very reasonably deduced from hence? And therefore, finally, may we not look upon this Custom of learning Youth to read by the Holy Bible and absurd Profanation, and the most sordid Abuse of the fame? (xi).

Material processes such as bedrivelled, daubed, and pulled to Pieces are employed as blistering physical attacks on religion, whereas Indifference, Contempt, or Aversion put the blame on the passive attitude of adults. Circumstantial elements (without any Erudition at all) nullify the action of instructors on children (bred up), whereas parents are censured for their meanness (Niggards) regarding the education of their children (little Learning they bestow on their Children). Further connotations of sex (prostituted), money (mercenary, opulent), and racism (Niggards) are introduced, turning education into a field of conflict or overflow channel of human depravity, where Infidelity and Profanation subvert the basic pillars of religion by collocating with the Grounds of Deism and the Holy Bible, respectively: "But such is the Effect of Custom, and inveterate Usage, and such the Weakness of human Nature, that we suffer our Bibles to be prostituted unconcernedly to a base and mercenary Interest [...]" (xii). In all this corrupt site of immorality and wickedness, Martin presents his grammar as a redeemer that will restore educational, social, and religious order to the world: "I HAVE long been persuaded, that nothing has been so much wanted in our English Schools as an Introduction to the English Language and Learning [...]" (v). What is more, the significance of his grammar is assumed to go beyond the educational sphere, as can be inferred by establishing a link with the following sentence: "Education of 
A CRITICAL DISCOURSE APPROACH TO BENJAMIN MARTIN'S PREFACE TO AN INTRODUCTION TO...

Children should be esteemed the most important Affair of Life [...]" (xxi). Through the mental process of cognition (esteem) and the implicit first-person plural as the agent of the passive verb, the author invites, or rather, implicitly imposes, the reader to reach that conclusion.

Consequently, in Martin's preface, education is presented as the central axis of human life. It functions as a polluting but also as a purifying element, and ultimately as a kind of religion in itself. From a state of frailty and depravity, Martin's preface leads the learner to a healing process triggered by proper teaching methods. But more specifically, it is Martin's grammar that may function as a remedy that can rescue the learner from the lowest levels of human condition. Therefore, as a kind of discourse strategy that proves the value of his grammar, the learner undergoes a process of misery and penance. Martin's grammar will restore the student as a learner but, most importantly, as a true believer and as a human being. Essentially, the religious dimension Martin assigns to education could be interpreted as a strategy to highlight the relevance of his grammar as an instrument of salvation.

As evinced through the analysis carried out in this paper, Martin's preface is characterised by the appearance of some powerful vocabulary that has a considerable effect at a discourse level. Martin makes use of shocking terms that occasionally may even be offensive to some of the participants described in the text. A hostile attitude pervades the preface through an extensive procedure of naturalised lexical cohesion based mainly on processes of repetition, synonymy, and collocation, the latter presenting the association of education and religion as a common-sense assumption. Other linguistic mechanisms, such as intensifiers, comparative and superlative forms, or emphatic adjectives (e.g., preposterous, deplorable, shocking) contribute to conveying an emphatic nature and great intensity to the text. Transitivity structures place the learner as a victim of traditional teaching methods, and what is more, as a victim of his parents. Transitivity arrangements do not only describe the deficiencies of traditional methods. The author tries to influence the perception of events by the reader as well. Throughout the preface, complex transitivity patterns include relational attributive structures whereby reality is evaluated. At the same time, through mental verbs of cognition, mainly with the first-person plural, the reader is placed as a witness of events. The execution of material processes of doing, either dispositive (doing to) or creative (bring about), are hindered as if symbolising the imposed inability of learners produced by mistaken teaching methods and to implicitly encourage a judgement of disapproval on the reader. The strategic purpose of this conflation of linguistic procedures may be to alert and provoke an immediate response on any potential buyer of the grammar. 
In Martin's preface, education acquires a significant religious dimension that also pervades the most essential aspects of human life. Sexual references and racist connotations shake up the reader's conscience and contribute to catching the reader's attention. However, education may also be negatively influenced by economic interests or be the source of unhappiness, obscurity, and of a chaotic existence. The most important pillars of the human being may collapse because of a deficient education system. Accordingly, Martin transmits a rather catastrophic idea of penance, disorder, and corruption produced by a defective education system.

\section{CONCLUSION}

This paper has tried to gain insight into the role of Martin as a grammarian through the analysis of his preface to An Introduction to the English Language and Learning (1754). The aim of the current paper was to describe the discourse structures used in Martin's preface to fulfil its advertising function and persuade the addressee to be a potential buyer or user of the grammar. As illustrated throughout this analysis, Martin's preface is characterised by the appearance of some powerful vocabulary with a considerable effect at a discourse level and also by the peculiarly exaggerated and aggressive tone emerging from the complex discourse structures used. These characteristics, along with the emphasis placed on the religious implications of education, confer some distinction to Martin within the discourse community of eighteenth-century grammarians. Within the corpus of prefaces selected in Fernández-Martínez (2016), Martin's preface stands out because of its linguistic uniqueness, specifically its hostile style and the religious implications of education. The religious dimension assigned to education unveils a discourse strategy whereby grammars are depicted as instruments of purification and, ultimately, as a kind of religion in itself. Through the analysis of his preface, Martin reveals himself as a grammarian of excess, gloomy, and apocalyptic in his assessment of reality. Martin presents an alarming preface that naturalises a catastrophic view of education as the source of human degeneracy, but also as the source of human salvation. He makes use of offensive and provocative insolence to activate an automatic response in the reader. Whatever the result, what is clear is that the uniqueness of his preface confers some singularity to Martin within the discourse community of English grammarians analysed until now by the author of this paper. Although more research is needed to extend the corpus of prefaces to English grammars under analysis, it could be stated that the peculiarities of Martin's preface contribute to enriching the discourse profile of the discourse community of eighteenth-century English grammarians. Far from being a factor to be overlooked, Martin's role as a linguist still deserves careful attention. 
A CRITICAL DISCOURSE APPROACH TO BENJAMIN MARTIN'S PREFACE TO AN INTRODUCTION TO...

\section{REFERENCES}

Auer, A. 2008. "Eighteenth-Century Grammars and Book Catalogues". Grammars, Grammarians and Grammar Writing in Eighteenth-Century England. Ed. I. Tieken-Boon van Ostade. Berlin and New York: Mouton de Gruyter. 57-75.

Beal, J. C. 2004. English in Modern Times. London: Arnold.

Chapman, D. 2008. "The Eighteenth-Century Grammarians as Language Experts". Grammars, Grammarians and Grammar Writing in Eighteenth-Century England. Ed. I. Tieken-Boon van Ostade. Berlin and New York: Mouton de Gruyter. 21-36.

Discenza, N. G. 2001. "Alfred's Verse Preface to the Pastoral Care and the Chain of Authority". Neophilologus 85 (4): 625-633.

Domínguez-Rodríguez, M. V. and A. Rodríguez-Álvarez. 2015. “The Reader is Desired to Observe [...]' Metacomments in the Prefaces to English School Grammars of the Eighteenth Century". Journal of Historical Pragmatics 16 (1): 86-108.

Eighteenth-Century English Grammars Database. 2010. Compiled by M. E. Rodríguez-Gil and N. Yáñez-Bouza. <http://www.alc.manchester.ac.uk/ subjects/lel/research/completedprojects/c18englishgrammars/ecegdatabase/>.

Fairclough, N. 1989. Language and Power. London: Longman.

Fairclough, N. 1995. Critical Discourse Analysis: The Critical Study of Language. London: Longman.

Fernández-Martínez, D. 2016. "Genre Structure in the Prefaces to EighteenthCentury English Grammars: A Study on a Selection of Prefaces from the ECEG Database". Neuphilologische Mitteilungen 117 (2): 289-313.

Genette, G. 1991. "Introduction to the Paratext". New Literary History 22 (2): 26172.

Halliday, M. A. K. 2004. Introduction to Functional Grammar. London: Edward Arnold.

Harbus, A. 2007. "Metaphors of Authority in Alfred's Prefaces". Neophilologus 91: 717-727.

Martin, B. 1754. An Introduction to the English Language and Learning. In Three Parts. London: W. Owen.

Martin, J. R. 1992. English Text: System and Structure. Amsterdam: Benjamins.

Martin, J. R. 2000. "Close Reading: Functional Linguistics as a Tool for Critical Discourse Analysis". Researching Language in Schools and Communities: Functional Linguistic Perspectives. Ed. Len Unsworth. London: Cassell. 275-302. 
Martin, J. R. and D. Rose. 2003. Working with Discourse: Meaning beyond the Clause. London: Continuum.

Millburn, J. R. 1973. "Benjamin Martin and the Development of the Orrery". The British Journal for the History of Science 6 (4): 378-399.

Millburn, J. R. 1976. Benjamin Martin: Author, Instrument-Maker, and 'Country Showman'. Leyden: Nordhoff International Publishing.

Oxford Dictionary of National Biography. 2004. J. R. Millburn, 'Martin, Benjamin (bap. 1705, d. 1782)'. Oxford University Press. <http://www.oxforddnb.com/ view/article/18175>. (Accessed 1 Sept 2015)

Reyk, W. V. 2009. "Educating Christian Men in the Eighteenth and Early Nineteenth Centuries: Public-School and Oxbridge Ideals". Journal for Eighteenth-Century Studies 32: 425-437.

Rodríguez-Álvarez, A. and M. E. Rodríguez-Gil. 2013. "Common Topics in Eighteenth-Century Prefaces to English School Grammars: An Application of the ECEG Database”. Transactions of the Philological Society 111 (2): 202-222.

Rogers, R., ed. 2011. An Introduction to Critical Discourse Analysis in Education. New York: Routledge.

Starnes, D. W. T. and G. E. Noyes. 1991. The English Dictionary from Cawdrey to Johnson 1604-1755. Studies in the History of the Language Sciences (Vol. 57). Amsterdam and Philadelphia: John Benjamins Publishing.

Teo, P. 2000. "Racism in the News: A Critical Discourse Analysis of News Reporting in Two Australian Newspapers". Discourse \& Society 11 (1): 7-49.

Tieken-Boon van Ostade, I. 1982. "Benjamin Martin the Linguist". Historiographia Linguistica 12 (1/2): 121-133.

Tieken-Boon van Ostade, I. 2008a. "Grammars, Grammarians and Grammar Writing: An Introduction”. Grammars, Grammarians and Grammar Writing in Eighteenth-Century England. Ed. Ingrid Tieken-Boon van Ostade. Berlin and New York: Mouton de Gruyter. 1-14.

Tieken-Boon van Ostade, I, ed. 2008b. Grammars, Grammarians and Grammar Writing in Eighteenth-Century England. Berlin and New York: Mouton de Gruyter.

Tieken-Boon van Ostade, I. 2008c. "The 1760s: Grammars, Grammarians and the Booksellers". Grammars, Grammarians and Grammar Writing in EighteenthCentury England. Ed. I. Tieken-Boon van Ostade. Berlin and New York: Mouton de Gruyter. 101-124.

Wang, J. 2010. "A Critical Discourse Analysis of Barack Obama's Speeches". Journal of Language Teaching and Research 1 (3): 254-261. 
Watts, R. J. 1995. "Justifying Grammars: A Socio-Pragmatic Foray into the Discourse Community of Early English Grammarians". Historical Pragmatics: Pragmatic Developments in the History of English. Ed. A. H. Jucker. Amsterdam and Philadelphia: John Benjamins. 145-185.

Watts, R. J. 2008. "Grammar Writers in Eighteenth-Century Britain: A Community of Practice or a Discourse Community?" Grammars, Grammarians and Grammar Writing in Eighteenth-Century England. Ed. I. Tieken-Boon van Ostade. Berlin and New York: Mouton de Gruyter. 37-56.

Wells, R. A. 1973. Dictionaries and the Authoritarian Tradition: Study in English Usage and Lexicography. The Hague: Walter de Gruyter.

Young, L. and C. Harrison, eds. 2004. Systemic Functional Linguistics and Critical Discourse Analysis: Studies in Social Change. London: Continuum. 